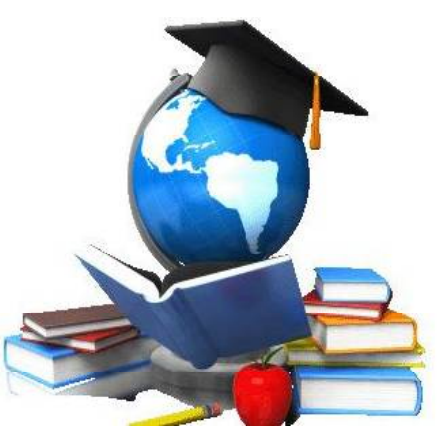

ПРОФЕСІЙНА ПІДГОТОВКА ТА ОСВІТА ДОРОСТИХ

ТЕТЯНА АТРОЩЕНКО, кандидат педагогічних наук, доиент, дочент кафедри педагогіки дошкільної та початкової освіти, Мукачівський державний університет, Украӥна ORCID 0000-0003-4595-1662 tatiyana05071976@gmail.com

ГАЛИНА ДЖАНДА, заступник директора з навчальнометодичної роботи коледжу, Закарпатський угорський інститут імені Ферениа Ракоиі II, Украӥна dzsandag@gmail.com

\title{
ТЕОРЕТИЧНІ ПІДХОДИ ДО ВИВЧЕННЯ НАСТУПНОСТІ ПРОФЕСІЙНОЇ ПІДГОТОВКИ МАЙБУТНЬОГО ВЧИТЕЛЯ ПОЧАТКОВИХ КЛАСІВ
}

\author{
TETIANA ATROSHENKO, Candidate of Pedagogical Sciences, Associate \\ Prof., Associate Professor at the Department of Theory and Methodology \\ of Primary Education at Mukachevo State University \\ GALINA DZHANDA, deputy headmistress of educational and \\ methodological work of the Vocational School of Ferenc Rakoczi II. \\ Transcarpathian Hungarian College of Higher Education
}

\section{THEORETICAL APPROACHES TO LEARNING CONTINUITY IN PROFESSIONAL TRAINING OF FUTURE ELEMENTARY CLASS TEACHERS}

У статті проведено теоретичний аналіз проблеми наступності професійної підготовки майбутнього вчителя початкових класів. Виявлено багатогранність поняття "наступність", яке традиційно розглядається як принцип і пояснюється специфікою педагогічного процесу. Наступність розглядається авторами як стан, згідно з яким забезпечується об'єктивний системний зв'язок попереднього і наступного етапів організації навчального процесу на методологічному й методичному рівнях 3 метою його оптимізації та адаптації студентів до нових етапів навчання.

Ключові слова: наступність, учитель початкових класів, професійна підготовка, педагогічний принцип, безперервна освіта.
Summary. The article carries out a theoretical analysis of the problems of continuity in professional training of future elementary class teachers. The versatile concept of "continuity" is revealed which is traditionally regarded as a principle and explained by the specifics of the pedagogical process. Continuity is considered by the authors as a condition according to which an objective systematic connection is provided between the previous and next stages of organizing the teaching process on methodological and methodical grounds in order to optimize and adapt students to the new stages of teaching.

Key words: continuity, primary class teacher, professional training, pedagogical principle, lifelong education.

Мета: обгрунтувати теоретичні підходи наступності професійної підготовки майбутнього вчителя початкових класів.

Постановка проблеми в загальному вигляді. Особливістю сучасного етапу розвитку освіти $\epsilon$ iii безперервність протягом усього життя людини, що дозволяє осягнути нинішні й майбутні досягнення науки і техніки, адаптуватися в соціумі, реалізувати особистісний розвиток. Головними характеристиками безперервної освіти виступають: гнучкість, різноманітність, доступність у часі і просторі та індивідуалізація. Традиційно наступність розглядається як зв'язок між явищами у процесі розвитку в природі, суспільстві і пізнанні, коли нове, змінюючи старе, зберігає в собі деякі його елементи. Дане визначення вважаємо основою розуміння сутності педагогічної наступ- 
ності, яка має свої особливості у зв'язку із специфікою педагогічного процесу.

Якість підготовки вчителя є найважливішим критерієм, що визначає його конкурентоспроможність у жорстких умовах ринку праці. Можливість досягти педагогом високого рівня професіоналізму, його постійне самовдосконалення розглядаються як найважливіші показники гнучкості всієї системи неперервної педагогічної освіти. Неодмінною умовою для такої підготовки є утілення принципу наступності, оскільки будь-яка педагогічна система, у тому числі і система неперервної педагогічної освіти, може успішно функціонувати лише за умови забезпечення наступності між етапами підготовки вчителя. Наступність виконує системоутворювальну функцію в організації неперервної педагогічної освіти та передбачає використання на кожному новому етапі того, що було досягнуто раніше. Однією з головних умов успішного функціонування системи неперервної педагогічної освіти є підпорядкованість попереднього ступеня етапу підготовки вчителя подальшій, більш високій за рівнем підготовки.

Зазначимо, що особлива роль у системі безперервної освіти відводиться вчителеві початкових класів, котрий, з одного боку, виступає як особистість, яка розвивається, а з іншого - у зв'язку із своєю професійною діяльністю, як людина, котра відповідає за умови, характер і перспективи розвитку іншої особистості - дитини молодшого шкільного віку. Вважаємо, що обгрунтування теоретичних підходів до вивчення наступності професійної підготовки майбутнього вчителя початкових класів має охоплювати змістовні, процесуальні та структурні характеристики досліджуваного явища.

Аналіз досліджень і публікацій. Дослідженню проблем професійної підготовки фахівців приділялася належна увага, зокрема, таким іiі аспектам, як: теоретикометодологічні засади підготовки майбутніх учителів початкової школи (К. Авраменко, В. Беспалько, В. Бондар, О. Дубасенюк, В. Желанова, Н. Кічук, С. Мартиненко, О. Мороз, 3. Плохій, О. Савченко, Л. Хомич та ін.); методологічні ос- нови ступеневої професійної підготовки фахівців у системі неперервної професійної освіти (М. Євтух, I. Зязюн, В. Кремень, С. Мамрич, Н. Ничкало, С. Сисоєва та ін.); проблеми ступеневої освіти вчителів початкових класів (С. Вітвицька, С.Власенко, О. Галус, І. Дарманська, Н. Казакова, Л. Хомич, О.Шквир та ін.). Не зважаючи на наявність різноаспектних наукових доробків, нині бракує системності у висвітленні теоретичних основ наступності у професійній підготовці майбутнього вчителя початкових класів, що і спонукало нас до більш грунтовного дослідження даного питання.

Виклад основного матеріалу дослідження. Висновком Лісабонського саміту (2000 р.) є те, що Європа вже вступила в "епоху знань", тому успішний перехід до економіки і суспільства, заснованих на знаннях, повинен супроводжуватися процесом безперервної освіти - "освіти впродовж життя" (lifelong learning). Відповідно європейські системи освіти мусять не тільки закласти основу для наступних змін, але і самі змінитися. Головна ідея нового підходу полягає в тому, що безперервна освіта перестає бути тільки одним з аспектів освіти і перепідготовки; вона виступає основним принципом освітньої системи та участі в ній людини протягом усього безперервного процесу її навчальної діяльності. Для цього визначено шість ключових принципів: базові знання та навички для всіх; збільшення інвестицій у людські ресурси; інноваційні методики викладання і навчання; нова система оцінки отриманої освіти; наставництво та консультування; "наближення до дому" (Меморандум).

Рух української системи освіти до європейських стандартів вимагає відповідних змін у фаховій підготовці майбутніх учителів початкових класів, зокрема, акценту на проблемі наступності в цій підготовці.

Наступність як комплексне педагогічне явище розглядалася протягом тривалого часу рядом дослідників у різних напрямах.

Український педагогічний енциклопедичний словник тлумачить поняття "наступність" у навчанні як "послідовність і системність у розміщенні навчального матеріалу, зв'язок і узгодженість ступенів і етапів навчально-виховного процесу... може здійснюватися при переході від одного уроку до наступного, ... року навчання до наступного" (Гончаренко, 2011, с. 309).

У філософському вимірі наступність часто ототожнюється 3 поняттям "традиція" у культурному аспекті, однак наступність є терміном значно ширшим, комплексним, який формується 3 існуючих традицій і таких, які "віджили" й не відповідають вимогам сучасності. До прикладу, М. Зав'ялова розглядає "наступність" як зв'язок та збереження, утримання й одночасне "відкидання", втрату й відторгнення певних сторін, форм, елементів попереднього розвитку ( $3 a-$ вьялова, 1988, с. 126).

Загалом, як зазначає М. Савельєв, філософське трактування "наступності" є основою організації безперервної освіти. 3 точки зору організації едукаційного процессу, філософські погляди на наступність $\epsilon$ лише частково правильними, оскільки обгрунтовані винятково 3 позиції діалектичного підходу. Пояснюється це тим, що наступність необхідно розглядати не лише в культурно-змістовому та в аспекті людських взаємин, але і з позиції форм організації навчального процесу й використання оптимальних методів навчання (Савельєв, 2018, c. 35).

Не менше уваги дослідженню поняття "наступність" приділяли психологи: Л. Виготський, Д. Ельконін, В. Звягінський, Ю. Кулюткін, С. Рубінштейн та інші. У рамках нашого вивчення грунтовною вважаємо думку Л. Виготського, що освіта "повинна бути зорієнтована на вчорашній та завтрашній день дитячого розвитку", тобто розвиток має акумулюватися послідовно на основі попередньо сформованих властивостей особистості. Науковець справедливо зазначає, що "навчити дитину можна лише тому, що вона здатна вивчити" (Bblготский, 1983, с. 252).

Найбільш широко різні аспекти проблеми наступності висвітлені в педагогічних дослідженнях. Це наукові роботи А. Богуш, Р. Гуревича, I. Ігнатенко, Л. Каращука, А. Кухти, А. Литвина, Л. Порядченко, М. Прокоф'євої, М. Савельєва, О. Савченко та інших. Погоджуємося з О. Савченко, котра розгля- 
дає наступність як: "принцип освіти, який забезпечує зв'язок та узгодженість мети, змісту та організаційно-педагогічних етапів навчально-виховного процесу" (Савченко, 1999, с. 45).

Македонська дослідниця S. Jovanova-Mitkovska пояснює наступність професійної підготовки як щоденне професійне та особистісне зростання вчителя, тривалий безперервний процес, який починається від початку підготовки до професії та триває до кінця життя; процес, який реалізується різними способами, що означає розвиток 3 новими знаннями, уміннями, навичками, стратегіями у відповідних галузях компетентності та застосування сучасних технологій (Jovanova-Mitkovska, 2010, c. 2922).

Отже, сутність наступності розкрита в різних науково-педагогічних дослідженнях. Вона $є$ правилом навчання, що забезпечує реалізацію, у першу чергу, таких принципів, як: науковість, систематичність, послідовність, доступність; установлює зв'язки між новими і старими знаннями як елементами цілісної системи; визначає зв'язки між знаннями, що повідомляються на одному уроці і в різних темах курсу, між матеріалом різних предметів; показує, що на черговому етапі навчання не слід затримувати учнів на рівні попереднього: конструктивніше відновлювати старе у процесі наступної роботи над новим матеріалом; здійснює послідовний зв'язок у роботі окремих класів і шкільних ступенів шляхом використання таких засобів, як узгодження програм і підручників, повторення матеріалу, проведення узагальнювальних занять у попередньому класі та ін.; забезпечує послідовність переходу класу від одних педагогів до інших: учителям молодших класів потрібно знати програму наступних класів і майбутні вимоги до учнів; педагогам старших класів - знати рівень підготовки їх нового контингенту, для чого необхідно вивчати його попередньо, сприяючи ретельнішій підготовці учнів до наступного класу.

Ю. Шереметьева розуміє наступність у змісті професійної підготовки як безперервний процес розгортання структурних компонентів змісту, поступовий перехід від одного етапу навчання до іншого, поступове ускладнення навчальної інформації, послідовну зміну рівня вимог до обсягу і глибини засвоєння знань, умінь і навичок. Кожен новий етап навчання повинен бути пов'язаний $з$ попереднім, слугувати передумовою для подальшого навчання. Зв'язок і наступність етапів навчання сприяє доступності навчального матеріалу, міцності його засвоєння, поступовому нарощуванню складності й розвитку пізнавальних здібностей студентів, що забезпечує системність у формуванні знань, умінь i навичок у майбутніх педагогів (Шереметьева, 2010, с. 10).

Слід зазначити, що наступність у педагогіці традиційно подана як принцип. А. Мороз зазначає, що "наступність - це загальнопедагогічний принцип, який стосовно навчання вимагає постійного забезпечення нерозривного зв'язку між окремими сторонами, частинами, етапами та ступенями навчання і всередині них; розширення і поглиблення знань, набутих на попередніх етапах навчання; перетворення окремих уявлень і понять у чітку систему знань, умінь і навичок; поступально-висхідного розгортання усього процесу відповідно до змісту, форм і методів роботи при обов'язковому врахуванні якісних змін, які відбуваються в особистості учня і студента" (Мороз, 1972, с. 10).

Досить часто принцип наступності об'єднують з іншими загальнопедагогічними принципами. Одні автори розглядають його у взаємозв'язку з принципом доступності, інші - 3 принципом науковості, послідовності і систематичності, треті - 3 принципом міцності тощо. Проте, на думку А. Литвина, наступність як загальнопедагогічний принцип вимагає неперервного зв'язку між окремими сторонами, частинами і ступенями навчання; розширення й поглиблення знань, здобутих на попередніх етапах навчання; перетворення окремих уявлень і понять у систему знань, умінь і навичок, необхідних для професійної діяльності; поступально-висхідного характеру розгортання змісту професійної підготовки. Дослідження проблеми наступності знань дозволяє подолати низку практичних труднощів у професійній освіті, зокрема, розроблення критеріїв добору змісту навчального матеріалу, систематизації знань на рівні навчально-пізнавального процесу загалом, усунення дублювання під час вивчення споріднених навчальних дисциплін і т. i. (Литвин, 2002, с. 9).

У нашому дослідженні наступність подана нами як стан, згідно з яким забезпечується об'єктивний системний зв'язок попереднього і наступного етапів організації навчального процесу на методологічному та методичному рівнях 3 метою його оптимізації й адаптації студентів до нових етапів навчання. Методологічний рівень пов'язаний 3 найбільш загальними питаннями реалізації наступності в системі освіти, а саме: виділенням етапів, характерних для певного виду наступності, а також встановленням характеру переходу від етапу до етапу. Методичний рівень передбачає забезпечення наступності цілей, змісту; методів, форм, технологій, способів діяльності та організації процесу навчання, контролю і управління, що дозволяє вести мову про наступність компонентів у рамках методичної системи, що охоплює вивчення певного ряду дисциплін і виконання різних видів науково-дослідницької діяльності.

Специфіка реалізації наступності у процесі професійної підготовки вчителя початкових класів пов'язана з їі метою - формуванням педагога відповідно до професійного стандарту "Вчитель початкових класів закладу загальної середньої освіти" (2018 р.) і відповідно до конкретної освітньої програми.

Висновки та перспективи подальших досліджень. Таким чином, на основі аналізу теоретичних джерел визначаємо, що: 1) Наступність має свою сутність, яка полягає у забезпеченні зв'язку між минулим, сьогоденням і майбутнім. Існують і більш специфічні визначення сутності наступності. На думку більшості авторів, стосовно системи виховання у загальноосвітній i вищій школах, сутність наступності полягає у збереженні тих чи інших форм і методів виховання при переході з одного освітньо-виховного ступеня на інший. Особливий інтерес представляють дані про вихідну психолого-педагогічної суті наступності, яка полягає в тому, що етапи навчання змінюють 
внутрішню позицію особистості, ii статус. Необхідно відзначити, що наступність також розглядається як закономірність, умова та засіб навчально-виховного процесу. 2) Наступність є закономірністю навчально-виховного процесу, оскільки зв'язок наступного 3 попереднім є відображенням найбільш міцних, істотних, загальних, необхідних, повторюваних, об'єктивних зв'язків і взаємин, що виникають і проявляються в ході даного процесу. Ця закономірність, що лежить в основі здійснення такого зв'язку, є також її умовою. Крім того, вона виступає як засіб, оснащуючи технологію зв'язку. Загалом усі зазначені вище підходи до визначення статусу наступності підкреслюють їі універсальність та поліфункціональність.

Наступність як дидактична одиниця найбільш влучно описує процеси комплексної взаємоузгодженості в діяльності педагогічних коледжів та університетів, тому в подальших дослідженнях ми зупинимося на аналізі принципу наступності в системі неперервної педагогічної освіти в системі "коледж - університет".

\section{СПИСОК ЛІТЕРАТУРИ}

Выготский, Л. С. (1983). Собрание сочинений. Т. 3. Москва : Педагогика.

Гончаренко, С. У. (2011). Український педагогічний енциклопедичний словник. Рівне : Волинські обереги.

Завьялова, М. П. \& Расторгуев, В. Н. (1988). Единство и преемственность сознания. Томск : ТГУ.
Литвин, А. В. (2002). Наступність у професійній підготовці фахівців машинобудівного профілю в системі "ВПУ - Вищі заклади освіти". (Автореф. дис. ...канд. пед. наук), Київ.

Меморандум непрерывного образования Европейского Союза (А Memorandum on Lifelong Learning). URL : www.znanie.org/docs/ memorandum.html.

Мороз, А. Г. (1972). Пути обеспечения преемственности в самостоятельной учебной работе учащихся средней общеобразовательной школы и студентов вуза (на материалах школ и вузов УССР). (Автореф. дис. ...канд. пед. наук), Киев.

Савельєв, М. Г. (2018). Наступність у професійній підготовці майбутніх вчителів технологій в умовах навчально-наукового комплексу "коледж - університет". (Дис. канд. пед. наук), Рівне.

Савченко, О. Я. (1999). Дидактика початкової школи : підручник для студентів педагогічних факультетів. Київ : Генеза.

Шереметьєва, Ю. О. (2010). Наступність у змісті професійної підготовки інженерівпедагогів швейного профілю. (Автореф. дис. ...канд. пед. наук), Київ.

Jovanova-Mitkovska, S. (2010). The need of continuous professional teacher development. Sciences 2, p. 2921-2926. doi: 10.1016/ j.sbspro.2010.03.44

\section{REFERENCES}

Vyigotskiy, L. S. (1983). Sobranie sochineniy. T. 3. Moskva : Pedagogika.

Honcharenko, S. U. (2011). Ukrainskyi pedahohichnyi entsyklopedychnyi slovnyk. Rivne : Volynski oberehy.

Zavialova, M. P. \& Rastorguyev, V. N. (1988). Edinstvo i preyemstvennost soznaniya. Tomsk : TGU.

Lytvyn, A. V. (2002). Nastupnist u profesiinii pidhotovtsi fakhivtsiv mashynobudivnoho profiliu $\mathrm{v}$ systemi "VPU-Vyshchi zaklady osvity". (Avtoref. dys... kand. ped. nauk), Kyiv.

Memorandum nepreryvnogo obrazovaniya Evropeyskogo Soyuza (A Memorandum on Lifelong Learning). URL : www.znanie.org/docs/ memorandum.html.

Moroz, A. G. (1972). Puti obespecheniya preyemstvennosti $\mathrm{V}$ samostoyatelnoy uchebnoy rabote uchashchikhsya sredney obshcheobrazovatelnoy shkoly i studentov vuza (na materialakh shkol i vuzov USSR). (Avtoref. dis. ...kand. ped. nauk), Kiyev.

Saveliev, M. H. (2018). Nastupnist u profesiinii pidhotovtsi maibutnikh vchyteliv tekhnolohii $\mathrm{v}$ umovakh navchalno-naukovoho kompleksu "koledzh - universytet". (Dys. ...kand. ped. nauk), Rivne.

Savchenko, O. Ya. (1999). Dydaktyka pochatkovoi shkoly: pidruchnyk dlia studentiv pedahohichnykh fakultetiv. Kiyev : Heneza.

Sheremetieva, Yu. O. (2010). Nastupnist $u$ zmisti profesiinoi pidhotovky inzhenerivpedahohiv shveinoho profiliu. (Avtoref. dys. ...kand. ped. nauk), Kiyev.

Jovanova-Mitkovska, S. (2010). The need of continuous professional teacher development. Sciences 2, p. 2921-2926. Doi: 10.1016/ j.sbspro.2010.03.4

Стаття надійшла 17.10.2019 р. 